\title{
PERTUMBUHAN LEMBAGA REKSADANA SYARIAH DI INDONESIA
}

\author{
Mukhamad Zakariya \\ Institut Agama Islam Diponegoro Nganjuk \\ e-mail: muhammad_zakariyah@yahoo.co.id
}

\begin{abstract}
The development of capital markets in Indonesia is encouraging. It brings a positive impact on the development of the investment system in accordance with the basic principles of sharia, in the capital markets sector in Indonesia, or better known by the term Islamic capital market. Islamic capital market is developed with the aim of accommodating the needs of Muslims in Indonesia that performs investment in capital market products in accordance with the basic principles of sharia. As we know that Indonesia is a country with a predominantly Islamic population makes Indonesia has a potential market for Islamic products. The problems of this study are the factors that influence the growth and development of Sharia Mutual Funds in Indonesia until 2014. The purpose of this study is to determine the factors that affect the growth and development of Sharia Mutual Fund in Indonesia, in particular on the list of Sharia Mutual Funds issued by OJK (Financial Services Authority) to 2014. This research is a qualitative research that does not test the hypothesis, but is intended to gain a deeper understanding of the various variables describing the past circumstances or phenomenon is happening today. The data used in this research is secondary data. This research is conducted by analyzing data collected by the author, which is derived from the issuer's financial statements, related websites, journals of sharia economic, sharia economic papers and other related sources. The analysis technique used by the author in this study is descriptive-qualitative method, a method that is done by collecting data, compiling and interpreting the results in order to obtain a clear picture of the growth and development of Sharia Mutual Funds in Indonesia until 2014. The results of this study shows that the main factor affecting the growth and development of Sharia Mutual Fund in Indonesia is the active role of government, both in terms of regulation or other supports, affecting various aspects, such as the development of product innovation.
\end{abstract}

Keywords: mutual funds, islamic mutual fund, the government of Indonesia

\section{Pendahuluan}

Keberadaan reksadana di Indonesia dapat dikatakan telah dimulai pada saat diaktifkannya kembali pasar modal di Indonesia. Pada saat itu, penerbitan reksadana dilakukan oleh persero (BUMN) yang didirikan khusus untuk menunjang kegiatan pasar modal Indonesia, sekalipun pada saat itu belum ada pengaturan khusus mengenai reksadana. Istilah reksadana lebih dikenal pada tahun 1990 dengan diizinkannya pelaku pasar modal untuk menerbitkan reksadana melalui Keppres Nomor 53 Tahun 1990 tentang Pasar Modal. Pada tahun 1997 yang diawali dengan krisis ekonomi di Indonesia. Kemacetan bank dalam menjalankan fungsi intermediasi berdampak cukup besar dalam memacetkan perekonomian secara keseluruhan. 
Tingkat suku bunga kredit yang sangat tinggi membuat dunia usaha sangat tercekik. Pemilik modal lebih tertarik menyimpan dananya dalam bentuk deposito. Hal ini masih berlanjut sampai sekarang tetapi dengan tingkat keparahan yang jauh lebih ringan. Permasalahan ini mengingatkan banyak pihak akan perlunya sebuah alternatif lain selain perbankan dalam fungsi intermediasi permodalan.

\section{Pengertian Reksadana}

Reksadana merupakan salah satu alternatif investasi bagi masyarakat pemodal, khususnya pemodal kecil dan pemodal yang tidak memiliki banyak waktu dan keahlian untuk menghitung risiko atas investasi mereka. Reksadana dirancang sebagai sarana untuk menghimpun dana dari masyarakat yang memiliki modal, mempunyai keinginan untuk melakukan investasi, namun hanya memiliki waktu dan pengetahuan yang terbatas. Selain itu, reksadana juga diharapkan dapat meningkatkan peran pemodal lokal untuk berinvestasi di pasar modal Indonesia. ${ }^{1}$

Umumnya, reksadana diartikan sebagai wadah yang dipergunakan untuk menghimpun dana dari masyarakat pemodal untuk selanjutnya diinvestasikan dalam portofolio efek oleh manajer investasi. Mengacu kepada Undang-Undang Pasar Modal Nomor 8 tahun 1995, pasal 1 ayat (27) didefinisikan bahwa reksadana adalah wadah yang dipergunakan untuk menghimpun dana dari masyarakat pemodal untuk selanjutnya diinvestasikan dalam portofolio efek oleh manajer investasi.

Ada tiga hal yang terkait dari definisi tersebut di atas. Pertama, adanya dana dari masyarakat pemodal. Kedua, dana tersebut diinvestasikan dalam portofolio efek. Ketiga, dana tersebut dikelola oleh manajer investasi. Dengan demikian, dana yang ada dalam reksadana merupakan dana bersama para pemodal, sedangkan manajer investasi adalah pihak yang dipercaya untuk mengelola dana tersebut.

\section{Pengertian Reksadana Syariah}

Reksadana syariah, mengandung pengertian sebagai reksadana yang pengelolaan dan kebijakan investasinya mengacu pada syariat Islam. Reksadana syariah, misalnya tidak diinvestasikan pada saham-saham atau obligasi dari perusahaan yang pengelolaan atau produknya bertentangan dengan syariat Islam, seperti pabrik makanan/minuman yang mengandung alkohol, daging babi, rokok dan tembakau, jasa keuangan konvensional, pertahanan dan persenjataan serta bisnis hiburan yang berbau maksiat.

Pada dasarnya, reksadana syariah sama dengan reksadana konvensional, yang bertujuan mengumpulkan dana dari masyarakat, yang selanjutnya dikelola oleh manajer investasi untuk kemudian diinvestasikan pada instrumen-instrumen di pasar modal dan pasar uang. Instrumen itu seperti halnya saham, obligasi, deposito, sertifikat deposito, valuta asing dan surat utang jangka pendek (commercial paper). Reksadana syariah ini termasuk dalam kategori reksadana terbuka (kontrak investasi kolektif).

\section{Pandangan Syariah tentang Reksadana}

\footnotetext{
${ }^{1}$ T aufiq Hidayat, Investasi Syariah (J akarta: t.p., 2011), 91.
} 
Pada prinsipnya, setiap sesuatu dalam muamalat adalah dibolehkan selama tidak bertentangan dengan syariah, mengikuti kaidah fikih yang dipegang oleh Mazhab Hambali dan para fuqaha łainnya, yaitu prinsip dasar dalam transaksi dan syarat-syarat yang berkenaan dengannya ialah boleh diadakan selama tidak dilarang oleh syariah atau bertentangan dengan $n a s\}$ syariah. Allah memerintahkan orang-orang yang beriman agar memenuhi akad yang mereka lakukan seperti yang disebutkan di dalam al-Quran:

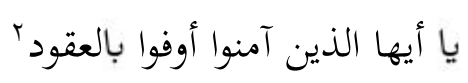

"Hai orang-orang yang beriman, penuhilah akad-akad itu".

Syarat-syarat yang berlaku dalam sebuah akad adalah syarat-syarat yang ditentukan sendiri kaum muslimin, selama tidak melanggar ajaran Islam. Rasulullah memberi batasan tersebut dalam hadits:

$$
\text { عن عمرو بن عوف أن رسول الله صلى الله عليه وسلم قال الصلح جائز بين المسلمين إلا صلحا حرم حلالا أو }
$$

"Perdamaian itu boleh antara orang-orang Islam kecuali perdamaian yang mengharamkan yang halal atau menghalalkan yang haram. Orang-orang Islam wajib memenuhi syarat-syarat yang mereka sepakati kecuali syarat yang mengharamkan yang halal atau menghalalkan yang haram".

Dalam reksadana konvensional berisi akad maumalah yang dibolehkan dalam Islam, yaitu jual beli dan bagi hasil (mudłrabah atau mushazakah). Dan di sana terdapat banyak maslahat, seperti memajukan perekonomian, saling memberi keuntungan di antara para pelakunya, meminimalkan resiko dalam pasar modal dan sebagainya. Namun, di dalamnya juga ada hal-hal yang bertentangan dengan syariah, baik dalam segi akad, operasi, investasi, transaksi dan pembagian keuntungannya.

Syariah dapat menerima usaha semacam reksadana sepanjang hal tersebut tidak bertentangan dengan syariah. Wahbah al-Zuhaily mengatakan bahwa setiap syarat yang tidak bertentangan dengan dasar-dasar syariat dan dapat disamakan hukumnya (diqiyaskan) dengan syarat-syarat yang sah. ${ }^{4}$ Prinsip dalam berakad harus mengikuti hukum yang telah digariskan oleh Allah yang disebutkan dalam al-Quran:

$$
\text { يا أيها الذين آمنوا لا تأكلوا أموالكم بينكم بالباطل إلا أن تكون بتحارة عن تراض منكمه }
$$

"Hai orang-orang beriman, janganlah kamu saling memakan harta sesamamu dengan jalan yang batil, kecuali dengan jalan perniagaan yang berlaku dengan suka sama suka diantara kamu.....".

\footnotetext{
${ }^{2}$ Q.S. al-M aidah:1.

3 M uhammad ibn Isa al-T urmudzi, Sunan al-Turmudzi, Jilid 3 (B eirut: Dar al-G harb al-Islami, 1998), 28.

${ }^{4}$ Wahbah al-Zuhaily, al-Figh al-Islami wa A dillatuh (B eirut: Dar al-Fikr, t.t.), 200.

${ }^{5}$ Q.S. al-Nisa':29.
} 


\section{Pihak dalam Reksadana}

1. Investor

Masyarakat luas yang menginvestasikan dananya dalam bentuk pembelian portofolio efek dari reksadana.

2. Manajer Investasi

Pihak yang kegiatan usahanya mengelola portofolio efek untuk para nasabah atau mengelola portofolio investasi kolektif untuk sekelompok nasabah. Adapun tugas-tugas manajer investasi meliputi :

a. Membuat aset alokasi untuk investor

b. Menyusun dan mengimplementasikan strategi investasi

c. Pengelolaan portofolio (jual atau beli instrumen)

d. Meminimumkan risiko investor

e. Menyesuaikan portofolio investasi dengan perubahan-perubahan yang terjadi pada iklim pasar investasi (ekonomi makro, inflasi, suku bunga dan kondisi sosial politik.

3. Bank Kustodian

Bank kustodian adalah pihak yang kegiatan usahanya adalah memberikan jasa penitipan efek dan harta lain yang berkaitan dengan efek serta jasa lain, termasuk menerima deviden, dan hak-hak lain, menyelesaikan transaksi efek, dan mewakili pemegang rekening yang menjadi nasabahnya. Adapun kewajiban bank kustodian :

a. Memberikan pelayanan penitipan kolektif sehubungan dengan kekayaan reksadana.

b. Menghitung nilai aktiva bersih dari unit penyertaan setiap hari bursa.

c. Membayar biaya-biaya yang berkaitan dengan reksadana atas perintah manajer investasi.

d. Menyimpan catatan secara terpisah yang menunjukkan semua perubahan dalam jumlah unit penyertaan, jumlah unit penyertaan, serta nama, kewarganegaraan, alamat, dan indentitas lainnya dari para pemodal.

e. Mengurus penerbitan dan penebusan dari unit penyertaan sesuai dengan kontrak.

f. Memastikan bahwa unit penyertaan diterbitkan hanya atas penerimaan dana dari calon pemodal.

4. Otoritas Jasa Keuangan (OJK)

Lembaga independen yang dibentuk menurut Undang-Undang No. 21 tahun 2011 yang berfungsi menyelenggarakan sistem pengaturan dan pengawasan yang terintegrasi terhadap keseluruhan kegiatan di dalam sektor jasa keuangan yang mencakup perbankan, pasar modal, perasuransian, dana pensiun, lembaga pembiayaan dan jasa keuangan lain.

5. Emiten

Perusahaan yang menerbitkan efek untuk ditawarkan kepada publik.

6. Dewan Pengawas Syariah

Yang bertugas mengawasi produk-produk reksadana syariah agar sesui dengan prinsip-prinsip syariah.

\section{Mekanisme Operasional dalam Reksadana Syariah}

1. Mekanisme operasional

a. Antara pemodal dengan manajer investasi dilakukan dengan sistem wakatah. 
b. Antara manajer investasi dan pengguna dilakukan dengan sistem mudłt $\overrightarrow{a b a h}$.

2. Karakteristik sistem mud lॄabah

a. Pembagian keuntungan antara pemodal (sqtes al-ma yang diwakili oleh manajer investasi dan pengguna investasi berdasarkan pada proporsi yang telah disepakati kedua belah pihak melalui manajer investasi sebagai wakil dan tidak ada jaminan atas hasil investasi tertentu kepada pemodal.

b. Pemodal hanya menanggung resiko sebesar dana yang telah diberikan.

c. Manajer investasi sebagai wakil tidak menanggung resiko kerugian atas investasi yang dilakukannya sepanjang bukan karena kelalaiannya (gross negligence/tafrith).

\section{Hak dan Kewajiban Manajer Investasi dan Bank Kustodian}

1. Manajer investasi berkewajiban untuk melaksanakan investasi bagi kepentingan pemodal, sesuai dengan ketentuan yang tercantum dalam prospektus.

2. Bank kustodian berkewajiban menjaga dan mengawasi dana pemodal dan menghitung nilai aktiva bersih per unit penyertaan dalam reksadana syariah untuk setiap hari bursa.

3. Atas pemberian jasa dalam pengelolaan investasi dan penyimpanan dana kolektif tersebut, manajer investasi dan bank kustodian berhak memperoleh imbal jasa yang dihitung atas persentase tertentu dari nilai aktiva bersih reksadana syariah.

4. Dalam hal manajer investasi dan atau bank kustodian tidak melaksanakan amanat dari pemodal sesuai dengan mandat yang diberikan atau manajer investasi dan atau bank kustodian dianggap lalai (gross negligenceltafrith), maka manajer investasi dan/atau bank kustodian bertanggung jawab atas risiko yang ditimbulkannya.

\section{Konsep Net Assets Value}

Konsep Net Assets Value atau Nilai Aktiva Bersih (NAB) adalah nilai aktiva reksadana setelah dikurangi nilai kewajiban reksadana tersebut. NAB merupakan total nilai investasi dan kas yang dipegang (uninvested) dikurangi dengan biaya-biaya hutang dari kegiatan operasional yang harus dibayarkan. Besarnya NAB bisa berfluktuasi setiap hari, tergantung pada perubahan nilai efek dari portofolio. Meningkatnya NAB mengindikasikan naiknya nilai investasi pemegang saham atau unit penyertaan. Begitu juga sebaliknya, menurunnya NAB berarti berkurangnya nilai investasi pemegang unit penyertaan atau saham. Bagi investor, $\mathrm{NAB} /$ unit memiliki beberapa fungsi, antara lain:

1. Sebagai harga beli/jual pada saat investor membeli/menjual unit penyertaan suatu reksadana.

2. Sebagai indikator hasil (untung/rugi) investasi yang dilakukan di reksadana dan penentu nilai investasi yang kita miliki pada suatu saat.

3. Sebagai sarana untuk mengetahui kinerja historis reksadana yang dimiliki investor.

4. Sebagai sarana untuk membandingkan kinerja historis reksadana yang satu dengan reksadana yang lain. 
Perkembangan Reksadana Syariah

Miliar Rp

Jumlah

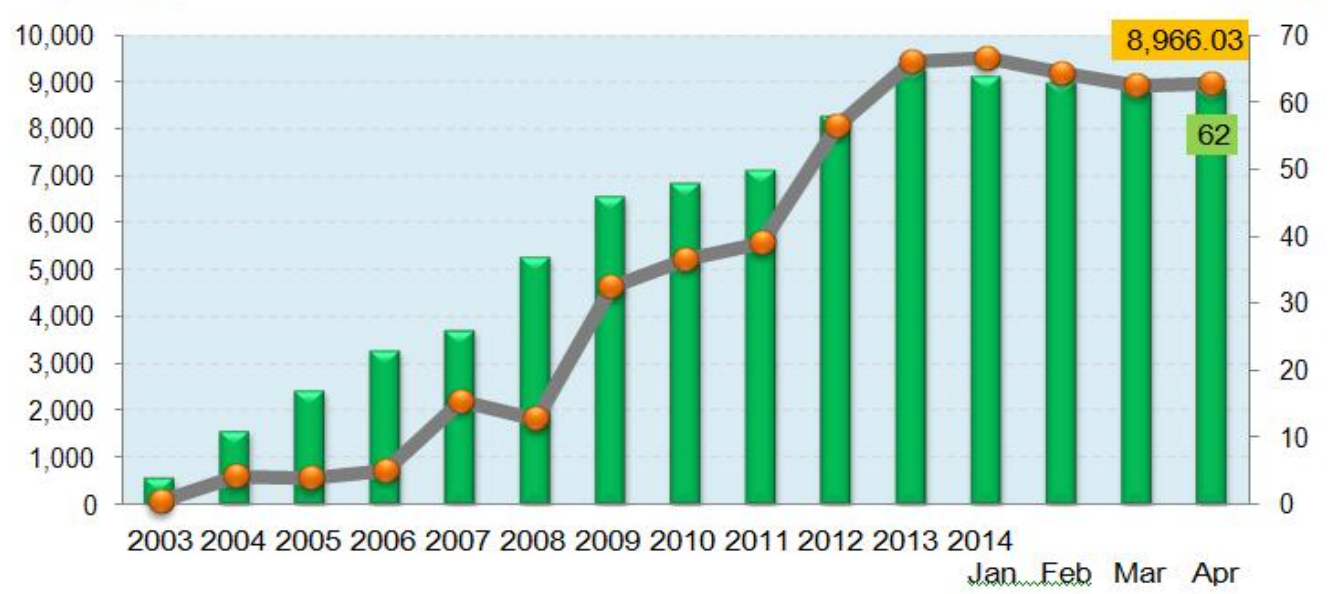

Reksa Dana Sxariah $\quad$ - Total NAB Reksa Dana Sxariah

Reksadana Syariah Per 30 April 2014

\begin{tabular}{|rl|r|r|}
\hline No & Jenis Reksa Dana Syariah & $\begin{array}{c}\text { Jumlah Reksa Dana } \\
\text { Syariah }\end{array}$ & $\begin{array}{r}\text { Total NAB } \\
\text { (Fip Miliar) }\end{array}$ \\
\hline 1 & Campuran & 18 & $4,329.17$ \\
\hline 2 & ETF & 1 & 99.45 \\
\hline 3 & Indeks & 1 & 159.41 \\
\hline 4 & Pasar Uang & 1 & 229.88 \\
\hline 5 & Pendapatan Tetap & 7 & 488.16 \\
\hline 6 & Saham & 16 & $2,707.40$ \\
\hline 7 & Terproteksi & 18 & 952.57 \\
\hline
\end{tabular}

Reksadana Saham

\begin{tabular}{|c|l|r|r|r|r|r|}
\hline \multirow{2}{*}{ No } & \multirow{2}{*}{ Nama Produk Reksadana } & \multirow{2}{*}{ NAB / UP } & \multicolumn{3}{|c|}{ Kinerja Reksadana } \\
\cline { 5 - 7 } & & & 1 Hari & 1 Bulan & 1 Tahun & 3 Tahun \\
\hline \hline 1 & Millenium Equity & $2,915.15$ & 1.18 & -1.52 & 64.41 & 102.25 \\
\hline 2 & Emco Mantap & $6,335.00$ & -0.27 & 2.63 & -0.42 & 63.17 \\
\hline 3 & MNC Dana Ekuitas & $3,233.29$ & -0.1 & 3.41 & -0.83 & 47.27 \\
\hline 4 & Cipta Syariah Equity & $1,799.54$ & -0.03 & 2.23 & 2.68 & 45.50 \\
\hline 5 & Lautandhana Equity Progresif & 827.59 & 0 & 5.49 & 4.88 & 43.64 \\
\hline 6 & Batavia Dana Saham Optimal & $2,239.94$ & -0.25 & 4.44 & 6.09 & 41.20 \\
\hline 7 & Pratama Equity & $1,697.50$ & 0.23 & 8.21 & 20.19 & 40.55 \\
\hline 8 & Schroder Dana Prestasi & $26,966.78$ & 0.19 & 5.36 & 4.17 & 39.43 \\
\hline 9 & BNP Paribas Pesona Syariah & $2,164.46$ & 0.3 & 3.25 & 0.04 & 39.21 \\
\hline 10 & Panin Dana Prima & $2,992.53$ & 0 & 5.3 & 3.58 & 38.74 \\
\hline 11 & Trim Syariah Saham & $1,354.81$ & -0.04 & 2.37 & -6.13 & 37.50 \\
\hline 12 & First State IndoEquity Peka Fund & $1,519.25$ & 0.14 & 6.28 & 0.27 & 34.64 \\
\hline 13 & Syailendra Equity Opportunity Fund & $3,081.03$ & 0.06 & 3.94 & -9.11 & 33.98 \\
\hline 14 & Schroder Dana Istimewa & $5,612.31$ & 0.21 & 5.08 & 1.96 & 33.00 \\
\hline 15 & Panin Dana Maksima & $61,339.85$ & -0.05 & 5.24 & 0.24 & 32.61 \\
\hline
\end{tabular}




\begin{tabular}{|c|c|c|c|c|c|c|}
\hline \multicolumn{7}{|c|}{ Reksadana Campuran } \\
\hline \multirow{2}{*}{ No } & \multirow{2}{*}{ Nama Produk Reksadana } & \multirow{2}{*}{ NAB / UP } & \multicolumn{4}{|c|}{ Kinerja Reksadana } \\
\hline & & & 1 Hari & 1 Bulan & 1 Tahun & 3 Tahun \\
\hline 1 & Sam Syariah Berimbang & $1,739.67$ & 0.17 & 2.02 & 3.85 & 52.35 \\
\hline 2 & Simas Satu & $4,912.56$ & -0.1 & 1.63 & 5.9 & 46.88 \\
\hline 3 & Nikko BUMN Plus & $1,996.81$ & -0.02 & 6.19 & 3.18 & 46.55 \\
\hline 4 & Sucorinvest Flexi Fund & $2,669.80$ & -0.13 & 4.35 & -4.98 & 41.86 \\
\hline 5 & MNC Dana Kombinasi & $1,919.41$ & -0.29 & 0.5 & -1.4 & 39.23 \\
\hline 6 & Kresna Flexima & $2,177.50$ & 0.06 & 6.31 & 23.58 & 36.32 \\
\hline 7 & Trim Syariah Berimbang & $1,978.58$ & 0 & 2.23 & -4.41 & 36.31 \\
\hline 8 & Panin Dana Unggulan & $5,292.51$ & -0.13 & 0.31 & 1.73 & 34.64 \\
\hline 9 & Syailendra Balance Opportunity Fund & $1,982.65$ & 0.42 & 3.53 & -4.14 & 33.32 \\
\hline 10 & Semesta Dana Maxima & $6,056.43$ & 0.24 & 2.45 & 4.99 & 32.01 \\
\hline
\end{tabular}

\begin{tabular}{|c|l|r|r|r|r|r|}
\hline \multicolumn{9}{|c|}{ Reksadana Pasar Uang } \\
\hline \multirow{2}{*}{ No } & \multirow{2}{*}{ Nama Produk Reksadana } & \multirow{2}{*}{ NAB / UP } & \multicolumn{4}{|c|}{ Kinerja Reksadana } \\
\cline { 5 - 8 } & & & $\mathbf{1}$ Hari & $\mathbf{1}$ Bulan & 1 Tahun & 3 Tahun \\
\hline \hline 1 & Mega Dana Kas & $1,106.84$ & 0.02 & 0.41 & 9.74 & 0 \\
\hline 2 & DPLK BRI Pasar Uang & $2,137.07$ & 0.03 & 0.81 & 7.97 & 0 \\
\hline 3 & BNI-AM Dana Likuid & $1,065.33$ & 0.03 & 0.65 & 6.02 & 0 \\
\hline 4 & Mandiri Investa Pasar Uang & $1,058.99$ & 0.03 & 0.51 & 5.41 & 0 \\
\hline 5 & Batavia Dana Kas Maxima & $1,058.11$ & 0.03 & 0.5 & 5.36 & 0 \\
\hline 6 & Phillip Money Market Fund & $1,057.37$ & 0.01 & 0.52 & 5.35 & 0 \\
\hline 7 & Panin Dana Likuid & $1,059.28$ & 0 & 0.41 & 5.32 & 0 \\
\hline 8 & CIMB-Principal Cash Fund & $1,057.12$ & 0.01 & 0.47 & 5.16 & 0 \\
\hline 9 & Trim Kas 2 & $1,057.59$ & 0.02 & 0.49 & 5.16 & 0 \\
\hline 10 & Equator Dana Kas & $1,055.59$ & 0.02 & 0.56 & 5.15 & 0 \\
\hline
\end{tabular}

\begin{tabular}{|c|l|r|r|r|r|r|}
\hline \multicolumn{9}{|c|}{ Pendapatan Tetap } \\
\hline \multirow{2}{*}{ No Noma Produk Reksadana } & \multirow{2}{*}{ NAB / UP } & \multicolumn{4}{|c|}{ Kinerja Reksadana } \\
\cline { 5 - 7 } & & & $\mathbf{1}$ Hari & $\mathbf{1}$ Bulan & $\mathbf{1}$ Tahun & 3 Tahun \\
\hline \hline 1 & Mandiri Investa Dana Syariah & $2,593.75$ & 0.11 & -0.08 & 2.14 & 66.14 \\
\hline 2 & Mandiri Investa Dana Utama & $1,684.99$ & 0.22 & -1.03 & -0.64 & 48.94 \\
\hline 3 & CIMB - Principal Bond & $17,110.48$ & -0.16 & -0.13 & -0.54 & 33.13 \\
\hline 4 & Dana Obligasi Stabil & $2,764.65$ & -0.07 & -0.19 & 10.81 & 30.56 \\
\hline 5 & Maybank GMT Dana Obligasi Plus & $2,510.43$ & -0.04 & -0.54 & 3.03 & 30.39 \\
\hline 6 & Indeks Harga Saham Gabungan & $4,418.76$ & 0.03 & 3.38 & -0.78 & 29.61 \\
\hline 7 & Prospera Obligasi & $2,530.40$ & 0.08 & -0.04 & -0.87 & 27.23 \\
\hline 8 & Simas Danamas Mantap Plus & $1,804.53$ & 0.02 & 0.59 & 7.09 & 26.12 \\
\hline 9 & Rido Dua & $2,289.65$ & 0.02 & -1.6 & -11.41 & 25.28 \\
\hline 10 & Danamas Stabil & $2,359.72$ & 0.02 & 0.6 & 6.97 & 25.17 \\
\hline
\end{tabular}




\section{Reksadana Syariah}

\begin{tabular}{|c|l|r|r|r|r|r|}
\hline \multirow{2}{*}{ No } & \multirow{2}{*}{ Nama Produk Reksadana } & \multirow{2}{*}{ NAB / UP } & \multicolumn{4}{|c|}{ Kinerja Reksadana } \\
\cline { 5 - 7 } & & & 1 Hari & 1 Bulan & 1 Tahun & 3 Tahun \\
\hline \hline 1 & Mandiri Investa Dana Syariah & $2,593.75$ & 0.11 & -0.08 & 2.14 & 66.14 \\
\hline 2 & Sam Syariah Berimbang & $1,739.67$ & 0.17 & 2.02 & 3.85 & 52.35 \\
\hline 3 & Cipta Syariah Equity & $1,799.54$ & -0.03 & 2.23 & 2.68 & 45.50 \\
\hline 4 & BNP Paribas Pesona Syariah & $2,164.46$ & 0.3 & 3.25 & 0.04 & 39.21 \\
\hline 5 & Trim Syariah Saham & $1,354.81$ & -0.04 & 2.37 & -6.13 & 37.50 \\
\hline 6 & Trim Syariah Berimbang & $1,978.58$ & 0 & 2.23 & -4.41 & 36.31 \\
\hline 7 & Schroder Syariah Balanced Fund & $1,857.95$ & 0.17 & 2.14 & 1.86 & 30.28 \\
\hline 8 & Danareksa Indeks Syariah & $2,572.54$ & 0.23 & 3.02 & -0.03 & 30.12 \\
\hline 9 & Indeks Harga Saham Gabungan & $4,418.76$ & 0.03 & 3.38 & -0.78 & 29.61 \\
\hline 10 & Manulife Syariah Sektoral Amanah & $3,259.44$ & 0.14 & 3.79 & -0.71 & 28.35 \\
\hline
\end{tabular}

\section{Pertumbuhan Reksadana Syariah di Indonesia}

Reksadana merupakan salah satu alternatif investasi bagi masyarakat pemodal yang menginginkan investasinya beresiko minimum. Pada intinya, reksadana dirancang untuk menghimpun dana dari masyarakat yang mempunyai waktu, pengetahuan, dan modal yang terbatas sehingga mampu meningkatkan peran pemodal lokal. Jika dana para pemodal diinvestasikan ke bank, maka dana tersebut akan dikelola pihak bank dan pemodal akan mendapatkan bunga tanpa perlu tahu bagaimana dana itu diinvestasikan. Apabila sebaliknya para pemodal menginvestasikan dananya kedalam reksadana, maka dana tersebut akan dikelola oleh manajer investasi dan pemodal akan mendapatkan hasil yang diwujudkan dalam Nilai Aktiva Bersih (NAB) per unit penyertaan yang akan dijelaskan bagaimana dana tersebut dialokasikan.

Pertumbuhan reksadana syariah mengalami kenaikan yang cukup pesat. Menurut data statistik bahwa sampai dengan tahun 2003 hanya ada empat reksadana syariah dimana hanya satu reksadana syariah yang dinyatakan efektif, sedangkan tahun 2004 terdapat sebanyak tujuh reksadana syariah baru yang dinyatakan efektif. Akhir 2004 secara kumulatif terdapat sebelas reksadana syariah dan sampai dengan april 2014 reksadana syariah berjumlah 62 reksadana syariah.

Dibandingkan produk-produk reksadana konvensional, tingkat pertumbuhan produk reksadana syariah terbilang lebih cemerlang, baik dari segi jumlah produk maupun dana kelolaan potensi perkembangan reksadana ini pun terbilang cukup besar. Selain dipicu oleh pertumbuhan ekonomi serta munculnya kesadaran masyarakat untuk berinvestasi, hal ini juga didorong oleh kondisi masyarakat Indonesia yang sebagian besar merupakan penganut agama Islam. Reksadana syariah berbasis campuran mencatat dana kelolaan sebesar 4,10 triliun rupiah atau 2,03\%, reksadana syariah berbasis terproteksi sebesar 1,12 triliun rupiah atau $0,56 \%$, reksadana syariah berbasis saham 2,83 triliun rupiah atau $1,40 \%$. Sedangkan, reksadana syariah berbasis indeks sebesar 158,29 miliar rupiah atau 0,08\%, reksadana syariah berbasis pendapatan tetap sebesar 480,61 miliar rupiah atau 0,24\% dan reksadana syariah pasar uang sekitar $0,12 \%$ atau 231,36 miliar rupiah. 


\section{Kesimpulan}

Dari penjelasan di atas, reksadana merupakan salah satu alternatif bagi para pemula yang ingin memasuki dunia investasi pasar modal. Karena dengan berinvestasi di lembaga reksadana memikiko resiko yang lebih rendah dibandingkan kita berinvestasi sendiri dalam dunia pasar modal. Dan dalam berinvestasi dalam reksadana tidak harus memiliki modal terlalu besar namun modal awal yang disertakan dalam reksadana tergantung kepada kemampuan investor.

Pada dasarnya, reksadana syariah sama dengan reksadana konvensional yang bertujuan mengumpulkan dana dari masyarakat yang selanjutnya dikelola oleh manajer investasi untuk kemudian diinvestasikan pada instrumen-instrumen di pasar modal dan pasar uang. Instrumen itu seperti halnya saham, obligasi, deposito, sertifikat deposito, valuta asing dan surat utang jangka pendek (commercial paper). Reksadana syariah ini termasuk dalam kategori reksadana terbuka (kontrak investasi kolektif).

Untuk melakukan investasi reksadana, investor harus mengenal jenis risiko yang berpotensi timbul apabila membeli reksadana adalah risiko menurunnya NAB (Nilai Aktiva Bersih) unit penyertaan, risiko likuiditas, risiko pasar, risiko default. Dari hasil pendataan dan analisis terhadap data yang dikumpulkan, maka ditemukan faktor-faktor yang mempengaruhi pertumbuhan dan perkembangan reksadana syariah di Indonesia sampai dengan tahun 2014, yaitu:

1. Nilai Aktiva Bersih yang merupakan suatu alat ukur kinerja dari keberhasilan reksadana syariah tersebut sehingga apabila NAB naik maka naik juga nilai investasinya.

2. Jenis reksadana syariah yang jumlahnya lebih banyak dibandingkan dengan yang lain tercerminkan bahwa reksadana syariah tersebutlah yang mempunyai potensi terbaik.

3. Masih belum meratanya pemahaman atau pengetahuan masyarakat Indonesia tentang investasi di pasar modal yang berbasis syariah.

Reksadana memiliki beberapa manfaat yang menjadikannya sebagai salah satu alternatif investasi yang menarik dikelola oleh manajemen profesional, yaitu diversifikasi investasi, transparansi informasi, likuiditas yang tinggi, biaya rendah.

\section{Daftar Rujukan}

al-Turmudzi, Muhammad ibn Isa. Sunan al-Turmuæhi, jilid 3. Beirut: Da〉 al-Gharb alIslamiiy, 1998.

al-Zuhaily, Wahbah. al-Fiqh al-Isläriy wa Adillatuh. Beirut: Daßal-Fikr, t.t..

Hidayat, Taufiq. Investasi Syariah. Jakarta: t.p., 2011.

Huda, Nurul dan Mustafa Edwin Nasution. Investasi Pada Pasar Modal Syariah. edisi revisi, cet. 2. Jakarta: Kencana, 2008.

Pratomo, Eko Priyo dan Nugraha Ubaidillah. Reksa Dana dalam Solusi Perencanaan di Era Modern. Jakarta: t.p., 2010.

http://www.ojk.go.id

http://www.reksadanasyariah.net/2008/08/keputusan-fatwa-mui-tentang-reksadana.html. 